
cited.

\title{
PEMBERIAN SANKSI DANA ZAKAT KEPADA BENDAHARA PEMERINTAH DI PAGALARAM
}

\section{Fitria Kusumawardhani}

Fakultas Hukum Universitas Lancang Kuning

Email fitriakusumawardhani@ rocketmail.com

Received: 20 Agustus 2019; Accepted: 03 September 2019; Published: 29 Oktober 2019

\begin{abstract}
This study aims to find out and analyze the granting of alms charity funds to the Government Treasurer in Pagalaram City for the implementation of zakat funds carried out by the Government Treasurer.

The research method used is normative law, namely the legal systematics that identifies the basic meaning in law.

analyzed using statistics or mathematics or the like, but describe descriptively from the data obtained and also the method of inductive thinking is the conclusion that a statement or dalili that is special becomes a general statement or case, the data source uses secondary data namely Primary Legal Material namely, Secondary Legal Material Research and tertiary Legal Material.

The purpose of this writing is to find out and identify and understand about the granting of zakat alms (BAZ) sanctions to government treasurers in Pagalaram city. Approach to Law Number 20 of 2011 concerning the Eradication of Corruption Crimes and also a theoretical approach to zakat and the Regulation of the Financial and Development Supervisory Agency.

The results of this study indicate that the embezzlement of funds carried out by the Government Treasurer on zakat funds is in the place of the Zakat Agency (BAZ) which should be used for people who need financial assistance, there can be empowered for something useful for the community to can be said to be less capable in income / income distributed by the Amil Zakat Agency (BAZ).
\end{abstract}

Keyword: Granting of Zakat Fund Sanctions, Government Treasurer, Amil Zakat Agency (BAZ).

\section{PENDAHULUAN}

\section{A. Latar Belakang}

Pancasila terdapat asas-asas yang bangsa yang mencapai kemerdekaan merupakan pencerminan tekad dan aspirasi bangsa Indonesia sebagai 
dengan perjuangan yang terdiri dari $: 1$

1. Asas ketuhanan mengamanatkan bahwa tidak boleh ada produk hukum nasional yang bertentangan dengan agama atau bersifat menolak atau bermusuhan dengan agama.

2. Asas perikemanusiaan mengamanatkan bahwa hukum harus melindungi warga negara dan menjunjung tinggi martabat manusia.

3. Asas persatuan kesatuan atau kebangsaan mengamanatkan bahwa hukum nasional yang berlaku bagi seluruh bangsa Indonesia, Hukum nasional berfungsi bagi seluruh bangsa Indonesia.

4. Asas demokrasi mengamanatkan bahwa dalam hubungan antara hukum dan kekuasaan, kekuasaan harus tunduk pada hukum bukan sebaliknya, kekuasaan pada rakyat dan wakil-wakilnya.

\footnotetext{
${ }^{1}$ Warkum Sumitro, Legislasi : Hukum Islam Transformatif, 2015, Malang : Setara Press, hal. 42
}

5. Semua asas keadilan sosial mengamanatkan bahwa warga negara

mempunyai hak yang sama dan semua orang sama dihadapan hukum.

Asas persatuan kesatuan atau kebangsaan mengamanatkan bahwa hukum nasional yang berlaku bagi seluruh bangsa Indonesia. Hukum nasional berfungsi bagi seluruh bangsa Indonesia. Salah satu bentuk hukum nasional ialah Badan Amil Zakat sebagai lembaga yang melakukan pengelolaan zakat secara nasional. BAZNAS merupakan Lembaga pemerintah nonstruktural yang bersifat mandiri dan bertanggung jawab kepada Presiden melalui Menteri Agama. Lembaga, badan dan sebagainya yang dimiliki oleh Pemerintah Pusat dan Pemerintah Daerah yang menjalankan usaha atau melakukan kegiatan untuk memperoleh penghasilan merupakan subyek pajak.

Hubungan manusia dengan Tuhan-Nya, dapat dilihat dari menunaikan kewajiban-kewajiban agama, sepeti shalat, zakat, puasa 


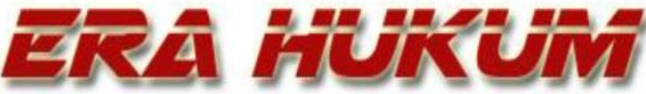

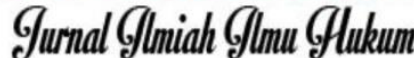 \\ Volume 17, No. 2, Oktober 2019}

dan lain-lain, sebagaimana disebutkan dalam Al-Qur'an : ${ }^{2}$

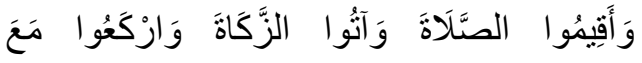

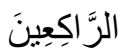

Artinya : "Dan didirikan shalat, tunaikanlah zakat, dan ruku'lah beserta orang-orang yang ruku". (Q.S Al-baqarah : 43).

Dalam kitab fiqih memberi merupakan infak, bersedekah dan zakat. Zakat Imam Asy-Syarkhasyi al Hanafi dalam kitabnya Al Mabsuth mengatakan bahwa dari segi bahasa "zakat" adalah tumbuh dan bertambah, disebut zakat, karena sesungguhnya ia menjadi sebab bertambahnya harta dimana Allag ta'ala menggantinya di dunia dan pahal di akhirat, sebagaimana firman-Nya :

قُلْْ إِنَّ رَبِّي يَبْسُطُ الرِّزْقَ لِمَنْ بَثَنَاءُ مِنْ عِبَادِهِ

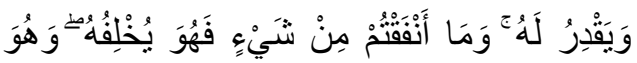

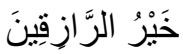

"Sesungguhnya Tuhanku melapangkan rezki bagi siapa yang dikehendaki-Nya di antara hambahamba-Nya dan menyempitkan bagi

\footnotetext{
${ }^{2}$ Drs. Dalizar Putra, Hak Asasi Manusia Menurut Al-Qur'an, 1995, Jakarta : PT. Al-Husna Zikra. hal. 17
}

Fitria Kusumawardhani Pemberian Sanksi Dana Zakat Kepada ... (siapa yang dikehendaki-Nya)". Dan barang apa saja yang kamu nafkahkan, maka Allah akan menggantinya dan Dialah Pemberi rezki yang sebaik-baiknya" QS. Saba' ayat 39..

Dalam penelitian Hamidy Thalib, Muhammad Irwan dan Ihsan Ro'is yang diperoleh di jurnal Pendayagunaan Zakat di Badan Amil Zakat Nasional Kota Pekanbaru Berdasarkan Undang-Undang Nomor 23 Tahun 2011 tentang Pengelolaan Zakat pernah meneliti tentang model pengelola zakat untuk mengatasi kemiskinan di Kota Bima. Dalam penelitiannya menyimpulkan bermacam-macam cara dalam pengelolaan zakat, yaitu ada yang sesuai dengan prinsip prinsip Islami dan ada yang belum sesuai dengan prinsip-prinsip Islami, yaitu tanpa berkoordinasi dengan pihak lain dengan menyalurkan zakat oleh amil itu sendiri dan tanpa mempublikasikan laporan kemasyarakat setempat. $^{3}$ Dalam penelitian Achmat Subekan yang berjudul Potensi Zakat Menjadi

\footnotetext{
${ }^{3}$ Muhammad Azani, Jurnal Pendayagunaan Zakat di Badan Amil Zakat Nasional Kota Pekanbaru Berdasarkan Undang-Undang Nomor 23 Tahun 2011 tentang Pengelolaan Zakat,Pekanbaru, 2017, hal 5.
} 
Bagian Keuangan Negara pengalokasian anggaran tersebut juga dimaksudkan untuk pemerataan kesejahteraan (pembangunan) rakyat sehingga terwujud pemerataan kesejahteraan bagi seluruh rakyat. Pencairan dana dari Rekening Kas Negara dilaksanakan oleh setiap kementerian/lembaga (pengguna anggaran) dengan menerbitkan Surat Perintah Membayar (SPM) kepada Menteri Keuangan selaku Bendahara Umum Negara (pemegang Rekening Kas Negara). ${ }^{4}$

Bendahara Pemerintah adalah pegawai yang ditunjuk oleh pemerintah untuk membayarkan belanja barang dan jasa serta modal yang dikeluarkan oleh pemerintah kepada rekanan pemerintah yang dananya berasal dari APBN, APBD dan sumber lainnya.

\section{Bendahara Pemerintah}

mempunyai kewajiban perpajakan maupun zakat yang agak berbeda dengan wajib pajak badan dan orang pribadi. ${ }^{5}$

4 Achmat Subekan, Jurnal Potensi Zakat Menjadi Bagian Keuangan Negara, 2016, Balai Diklat Keuangan Malang, hal. 9.

5 Wibowo Pajak, Artikel Pajak untuk Bendahara

Pemerintah,
Bendahara Pemerintah terdiri dari Bendahara Pemerintah Pusat Bendahara Pemerintah Daerah Bendahara Desa.

Titik sentral teori lembaga legislatif Islam adalah syura. Kata ini disebutkan satu kali dalam al-qur'an. Para pemikir politik Islam menjadikan kata syura ini sebagai landasan normatif teori lembaga legislatif Islam. Ada beberapa definisi syura yang diberikan beberapa pemikir muslim. Pertama syura adalah meminta pendapatan kepada para ahli untuk mengambil kebijakan yang dekat kepada kebenaran. Kedua syura adalah meminta pendapat kepada umat atau yang mewakilinya dalam masalahmasalah yang berhubungan dengan kepentingan publik. Ketiga, syura adalah wahana peran serta masyarakat dalam rangka tukar pendapat dalam membuat kebijakan publik. ${ }^{6}$ Subyek hukum adalah segala sesuatu yang dapat memperoleh hak dan kewajiban dari hukum. Yang

http://www.wibowopajak.com/2012/01/paj ak-untuk-bendahara-pemerintah.html, 2018

${ }^{6}$ Warkum Sumitro, Legislasi : Hukum Islam Transformaitif, Op. Cit, hal. 39. 
dapat memperoleh hak dan kewajiban dari hukum hanyalah manusia atau orang atau sesuatu yang dapat dipersamakan dengan orang yang sering kita kenal dengan istilah badan hukum.

Beberapa lembaga resmi yang dibentuk berdasarkan peraturan ialah

1. Badan Amil Zakat (BAZNAS)

2. Lembaga Amil Zakat (LAZ)

3. Unit Pengumpul Zakat (UPZ)

Dalam hal perjanjian, setiap perbuatan hukum yang bersegi dua merupakan perjanjian (oovereenkomst), pasal 1313 KUHPerdata "Perjanjian ain atau lebih.” Badan Usaha Milik Negara dan badan usaha milik daerah merupakan subjek pajak tanpa memperhatikan nama dan bentuknya sehingga setiap unit tertentu dari badan pemerintah, misalnya lembaga, badan dan sebagainya yang dimiliki oleh Pemerintah Pusat dan Pemerintah Daerah yang menjalankan usaha atau melakukan kegiatan untuk memperoleh penghasilan merupakan subyek pajak. Dalam pengertian perkumpulan termasuk pula asosiasi, persatuan, perhimpunan, atau ikatan dari pihak-pihak yang mempunyai kepentingan yang sama. Hal yang saling berkaitan adalah Bendahara Umum Pemerintah melakukan penggelapan dana kepada Badan Amil Zakat (BAZ).

Kasus yang diteliti oleh penulis ialah Keanggotaan Badan Amil Zakat (BAZNAS) beranggotakan 8 (delapan) orang dari unsur masyarakat dan 3 (tiga) orang dari unsur pemerintah. Kelembagaan ini mempunyai izin untuk mengumpulkan, pendistribusikan dan pendayagunaan zakat di Propinsi dan juga Kabupaten/Kota, namun tugas dari Bendahara Umum Negara ini melakukan tindak pidana korupsi cara pendekatan Lembaga Badan Pengawasan Keuangan dan Pembangunan. $^{7}$

\section{B. RUMUSAN MASALAH}

Berdasarkan uraian di atas, maka

\footnotetext{
${ }^{7}$ Sriwijaya Pos, Empat Bendahara Gaji di Pemkot Pagalaram Terbukti Korupsi Divonis Satu hingga Tiga Tahun Penjara, palembang.tribunews, 2017 diakses tanggal 11 September 2018
} 
untuk mencapai maksud dan tujuan dari penelitian, maka perlu dirumuskan permasalahan sebagai berikut :

1. Bagaimanakah Pemberian Sanksi Dana Zakat Kepada Bendahara Pemerintah di Kota Pagalaram ?

2. Bagaimanakah Perjanjian antara Badan Amil Zakat kepada Bendahara Pemerintah ?.

\section{PEMBAHASAN}

Polres Kota Pagaralam melakukan penahanan terhadap empat orang tersangka yang diduga terlibat dalam kasus penggelapan Dana Amilin Zakat (BAZ) Kota Pagaralam. Kasus ini sudah ditanda tangani Polres Pagaralam sejak 2014 ini akhirnya menetapkan empat tersangka sekaligus yaitu Surimawati Bendahara Gaji Satuan Polisi Pamong Praja Kota Pagaralam, Listianawati bendahara gaji Kecamatan Pagaralam Utara. Legimin Dinas Pekerjaan Umum dan Mukamin Bendahara Gaji Dinas Peternakan dan Perikanan Kota Pagaralam, setelah melakukan pengusuan Polres Kota Pagaralam melalui Unit Tindak Korupsi (TIPIKOR). Akhirnya melakukan penahanan terhadap keempat tersangka yang diduga menggelapan dana BAZ di empat Satuan Kerja Perangkat Daerah (SKPD) di lingkup Pemerintah Kota Pagaralam. Candra mengatakan, tindak pidana ini duga dilakukan tersangka sejak tahun 2004 hingga 2014, semesetinya potongan 2,5 persen dari gaji pegawai untuk BAZ tidak mereka setor ke rekening BAZ Kota Pagaralam, sehingga dalam kurun waktu 13 tahun berdasarkan hasil audit BPKP kerugian keuangan negara mencapai Rp 659.025.311. Keempat tersangka dikenai pasal 8 dan 2 ayat 1,2 Undang-Undang Nomor 31 Tahun 1999 junto Undang-Undang Nomor 20 Tahun 2011 tentang Pemerantasan Tindak Pidana Korupsi diancam hukuman minimal lima tahun penjara.

Titik sentral teori lembaga legislatif Islam adalah syura. Kata ini disebutkan satu kali dalam al-qur'an. Para pemikir politik Islam menjadikan kata syura ini sebagai landasan normatif teori lembaga 
legislatif Islam. Ada beberapa definisi syura yang diberikan beberapa pemikir muslim. Pertama syura adalah meminta pendapatan kepada para ahli untuk mengambil kebijakan yang dekat kepada kebenaran. Kedua syura adalah meminta pendapat kepada umat atau yang mewakilinya dalam masalahmasalah yang berhubungan dengan kepentingan publik. Ketiga, syura adalah wahana peran serta masyarakat dalam rangka tukar pendapat dalam membuat kebijakan publik. ${ }^{8}$

Subyek hukum adalah segala sesuatu yang dapat memperoleh hak dan kewajiban dari hukum. Yang dapat memperoleh hak dan kewajiban dari hukum hanyalah manusia atau orang atau sesuatu yang dapat dipersamakan dengan orang yang sering kita kenal dengan istilah badan hukum.

${ }^{8}$ Warkum Sumitro, Legislasi : Hukum Islam Transformaitif, Op. Cit, hal. 39.
Subjek pajak menurut UndangUndang Nomor 36 Tahun 2008 adalah : ${ }^{9}$

a. Orang Pribadi

b. Warisan yang belum terbagi sebagai satu kesatan

c. menggantikannya yang berlaku

d. Badan

e. Penjelasan Pasal 2 (1) huruf a

Orang pribadi sebagai subjek pajak dapat bertempat tinggal atau berada di Indonesia ataupun diluar Indonesia. Warisan yang belum terbagi sebagai satu kesatuan merupakan subjek pajak pengganti, menggantikan mereka yang berhak yaitu ahli waris. Penunjukkan warisan yang belum terbagi sebagai subjek pajak pengganti dimasukkan agar pengenaan pajak atas penghasilan yang bersal dari dari warisan tersebut tetap ada dilaksanakan.

Penjelasan Pasal 2 ayat (1) huruf $b$

"Badan adalah sekumpulan orang dan/atau modal yang merupakan kesatuan baik yang melakukan usaha maupun yang tidak melakukan usaha yang meliputi

\footnotetext{
${ }^{9}$ Undang-Undang Nomor 36 Tahun 2008 tentang Pajak Penghasilan
} 
perseroan terbatas, perseroan komanditer, perseroan lainnya, badan usaha milik negara atau badan usaha milik daerah dengan nama dan dalam bentuk apapun, firma, kongsi, korporasi, dana pensiun, persekutuan, perkumpulan, yayasan, organisasi massa, organisasi sosial politik atau organisasi lainnya, lembaga dan bentuk badan lainnya termasuk kontrak investasi kolektif dan bentuk usaha tetap.

Badan Usaha Milik Negara dan badan usaha milik daerah merupakan subjek pajak tanpa memperhatikannama dan bentuknya sehingga setiap unit tertentu dari badan pemerintah, misalnya lembaga, badan dan sebagainya yang dimiliki oleh Pemerintah Pusat dan Pemerintah Daerah yang menjalankan usaha atau melakukan kegiatan untuk memperoleh penghasilan merupakan subyek pajak. Dalam pengertian perkumpulan termasuk pula asosiasi, persatuan, perhimpunan, atau ikatan Dari Pihak-Pihak Yang Mempunyai Kepentingan Yang Sama.

Mengacu kepada UndangUndang Nomor 31 Tahun 1999 jo. Undang-Undang Nomor 20 Tahun 2001 yang mengklasifikasi perbuatan tindak pidana korupsi menjadi tujuh jenis di antara nya : merugikan keuangan negara, suap, gratifikasi, penggelapan dalam jabatan, perampasan perbuatan curang, konflik kepentingan. Pegawai negeri atau penyelenggara negara yang dengan maksud menguntungkan diri sendiri atau orang lain secara melawan hukum, atau dengan menyalahgunakan kekuasaannya memaksa seseorang memberikan sesuatu, membayar, atau menerima pembayaran dengan potongan, atau untuk mengerjakan sesuatu bagi dirinya sendiri.

\section{Pemberian Sanksi Dana Zakat} Kepada Bendahara Pemerintah di Kota Pagalaram

Lebih menjamin kepastian hukum, menghindari keragaman penafsiran hukum dan memberikan perlindungan terhadap hak-hak sosial dan ekonomi masyarakat, serta perlakuan secara adil dalam memberantas tindak pidana korupsi, maka ke empat Bendahara Gaji di Pemerintah Kota Pagaralam divonis satu atau tiga penjara.

Berdasarkan Undang-Undang Nomor 20 Tahun 2001 tentang 
Pemberantasan Tindak Pidana

Korupsi Pasal 8 Dipidana dengan pidana penjara paling singkat 3 (tiga) tahun dan paling lama 15 (lima belas) tahun dan pidana denda sedikit Rp150.000.000,00 (seratus lima puluh juta rupiah) dan paling banyak Rp750.000.000,00 (tujuh ratus lima puluh juta rupiah), pegawai negeri atau orang selain pegawai negeri yang ditugaskan menjalankan suatu jabatan umum secara terus menerus atau untuk sementara waktu, dengan sengaja menggelapkan uang atau surat berharga yang disimpan karena jabatannya, atau membiarkan uang atau surat berharga tersebut diambil atau digelapkan oleh orang lain, atau membantu dalam melakukan perbuatan tersebut.

\section{Perjanjian antara Badan Amil} Zakat kepada Bendahara

\section{Pemerintah}

\section{a. Pengertian Zakat}

Zakat adalah salah satu pilar (rukun) Islam, posisinya sama dengan syahadat, shalat puasa dan haji. Rasulullah bersabda :

\section{"Agama Islam dibangun di atas lima perkara Bersyahadat bahwasanya tidak}

adayang berhak di dan Nabi Muhammad itu utusan Allah, mendirikan shalat, menunaikan zakat, shaum di bulan Ramadhan dan berhaji ke Baitullah."(HR. Al-Bukhari Nomor 8 dan Muslim Nomor 16 dari sahabat Abdullah bin'Umar.

\section{b. Pembagian Zakat}

\section{1). Objek Zakat Profesi}

a) Pendapatan kotor (bruto). Pendapatan yang diterima dari mencapai hisab senila 85 gram emas dalam setahun, dikeluarkan 2,5\% zakatnya langsung ketika menerima sebelum dikurangi apapun.

b) Pendapatan bersih (neto), yaitu mengeluarkan zakat dari pendapatan yang diterima setelah dikurangi untuk kebutuhan pokok, membayar utang, untuk keperluan dirinya, keluarga dan yang menjadi tanggungannya, jika setelah dikuragi kebutuhan pokok masih mencapai nisab seniali 85 gram emas dalam setahun, maka wajib zakat. Jika tidak mencapai nishab tidak wajib zakat. 
Fitria Kusumawardhani Pemberian Sanksi Dana Zakat Kepada ...

c) Pendapatan minus biaya operasional, yaitu pendapatan yang diterima dikurangi biaya operasional kerja (seperti ongkos transpor, kebutuhan sehari-hari di tempat kerja, biaya alat kerja dan lain-lain), bila mencapai nishab, senilai 85 gram emas dalam setahun, maka wajib zakat. Biaya operasional ini di qiyas kan denganzakat hasil numi dan kurma serta sejenisnya.

\section{2).Pengaturan Zakat Penghasilan}

Zakat profesi adalah hal baru dalam pengelompokkan harta yang wajib dikeluarkan zakatnya. Istilah profesi diterjemahkan ke dalam bahasa Arab dengan dua kata :Pertama, Kata yang digunakan adalah al-mihnah. Kata ini dipakai untuk menyatakan pekerjaan yang lebih mengandalkan otak, oleh karena itu kaum profesional disebut almihaniyyun atau ashab al-minah, contoh : dokter, pengacara, penulis, konsultan hukum, seniman dan sebagainya. Kedua, pekerjaan yang terikat dengan pihak lain atau yang dikenal sebagai kerja profesi (Kasb al'amal) yaitu orang-orang yang melaksanakan pekerjaannya melalui sebuah kontrak atau perjanjian dengan pihak lain, contohnya seperti pegawai negeri, ketentaraan, polisi, pegawai pabrik dan pegawai perusahaan atau menjadi pekerja pada perorangan yang memperoleh gaji secara rutin pada setiap bulan. (fiqh Islam Wa Adillatuhu, -Jus 2 hal 865-866).

Pekerjaan dengan gaji tetap atau mempunyai sesuatu yang ia sewakan, seperti rumah atau sebidang tanah, jika ia tidak menabung dari sewaan atay gajinya tersebu maka tidak wajib mengeluarkan zakat meskipun jumlahnya banyak, sedangkan jika ia menabung dari hasil tersebut, maka ia wajib mengeluarkan zakatnya jika telah lewat haulnya (masa 1 tahun). Jika ia kesulitan dalam perhitungannya maka ia menentukan satu hari pada setiap tahun untuk membayar zakat, 
sebagaimana yang telah diterangkan di atas.

\section{3). Cara Pembayaran Pajak Profesi}

\section{Cara Mengeluarkan zakat}

Meng-qiyas-kan zakat
profesi dengan zakat emas atau perdagangan secara mutlak, mengignat karena kedua-duanya berbentuk usaha (kasab al-amal). Maka nishabnya senilai 85 gram emas murni, zakatnya $2,5 \%$ mempertimbangkan haul, dan seluruh pendapatan dalam tahun itu dijumlahkan dengan asumsi bahwa zakat adalah kewajiban yang dibebankan kepada nilainya (al-qimah), bukan kepada materinya (al-ain). Pembayaran dapat dilaksanakan pada akhir tahun (haul) atau dicicil pada setiap menerima gaji atau hasil profesi. (Fiqh al-zakat, 1/59-520). Meng-qiyas-kan zakat profesi dengan zakat penghasilan bumi baik nishab maupun kadarnya karena keduanya merupakan hasil jasa, Maka nishab-nya senilai 653 $\mathrm{kg}$, beras dan zakatnya 5\%, dikeluarkan pada saat menerima gaji atau jasa profesi tersebut.
Boleh juga mengeluarkan zakat profesi tanpa ketentuan nishab dan tahun yaitu pada saat diperolehnya (penerimaan).

\section{4).Perjanjian Bendahara}

Pemerintah kepada Badan Amil Zakat

Setiap hubungan hukum mempunyai dua segi : kekuasaan (wewenang, bevoegdheid) dengan tentangannya (kebalikannya) yakni : kewajiban (plicht). Kekuasaan ini yang oleh hukum diberi kepada seseorang, atau sesuatu badan hukum, karena hubungan hukumnya dengan orang lain, suatu badan hukum, karena hubungan-hukumnya dengan orang lain suatu badan hukum lain, biasanya disebut hak. Hukum sebagai himpunan peraturanperaturan yang mengatur hubungan kemasyarakatan, memberi kepada seseorang atau sesuatu badan hukum, hak yaitu wewenang kekuasaan, supaya berbuat sesuatu atau menuntut sesuatu badan hukum, yaitu weenang, kekuasaan, supaya berbuat sesuatu atau menuntut sesuatu badan hukum, supaya badan hukum suapaya berbuat atau menuntut, menagih sesuatu adalah 
keajaiban orang lain, badan hukum lain, supaya orang lain itu atau badan hukum lain itu, tunduk pada menghormati, hak tersebut atau perbuatan sesuatu yang diwajibkan oleh hak itu. ${ }^{10}$

Kekuasaan untuk memungut uang zakat adalah Bendahara Umum Pemerintah untuk mensejahteraan ekonomi masyarakat melalui gajigaji pegawai negeri sebesar $2,5 \%$ dari gaji yang diperoleh setiap bulan. Suatu perbuatan hukum yang bersegi satu adalah setiap perbuatan yang berakibat hukum (rechtsgelog) dan akibat hukum ditimbulkan oleh kehendak satu subyek hukum, yaitu satu pihak, saja (yang telah melakukan perbuatan itu). Suatu perbuatan hukum yang bersegi dua adalah setiap perbuatan yang akibat hukumnya ditimbulkan oleh kehendak dua subyek hukum, yaitu itu suatu perbuatan yang menyebbakan satu orang (subyek hukum) atau lebih mengikat dirinya pada seseorang (subyek hukum) 1 : dua fihak atau lebih. Setiap perbuatan hukum yang bersegi dua

\footnotetext{
${ }^{10}$ Undang-Undang Nomor 36 Tahun 2008 tentang Pajak Penghasilan
}

merupakan perjanjian (oovereenkomst), pasal 1313 KUHPerdata "Perjanjian lain atau lebih." Badan Usaha Milik Negara dan badan usaha milik daerah merupakan subjek pajak tanpa memperhatikan nama dan bentuknya sehingga setiap unit tertentu dari badan pemerintah, misalnya lembaga, badan dan sebagainya yang dimiliki oleh Pemerintah Pusat dan Pemerintah Daerah yang menjalankan usaha atau melakukan kegiatan untuk memperoleh penghasilan merupakan subyek pajak. Dalam pengertian perkumpulan termasuk pula asosiasi, persatuan, perhimpunan, atau ikatan dari pihak-pihak yang mempunyai kepentingan yang sama. ${ }^{11}$

$$
\text { Perjanjian Bendahara }
$$

Pemerintah kepada Badan Amil Zakat diawasi oleh BPKP untuk mengawasi kegiatan sosialisasi, asistensi atau pendampingan dan evaluasi merupakan kegiatan yang mulai digeluti BPKP, sedangkan

\footnotetext{
${ }^{11}$ Prof. Dr. Ahmadi Miru, S.H., M.H, 2008, Hukum Perikatan : Penjelasan Makna Pasal 1233 sampai 1456 BW, (Jakarta : Rajawali Press), hal. 74
} 
Fitria Kusumawardhani

audit investigatif dilakukan dilakukan dalam membantu aparat penegak hukum untuk menghitung kerugian keuangan negara.

\section{5). Badan Amil Zakat Nasional $(\text { BAZNAS })^{12}$}

Baznas berdasarkan Pasal 6 Undang-Undang Nomor 23 Tahun 2011 tentang Pengelolaan Zakat. BAZNAS merupakan lembaga yang berwenang melakukan tugas pengelolaan zakat secara nasional. Dalam melaksanakan tugas sebagaimana dimaksud dalam Pasal 6, BAZNAS menyelenggarakan fungsi:

a. Perencanaan pengumpulan, pendistribusian dan pendayagunaan zakat;

b. Pelaksanaan pengumpulan, pendistribusian dan pendayagunaan zakat;

c. Pengendalian pengumpulan, pendistribusian dan pendayagunaan zakat; dan

d. Pelaporan pertanggungjawaban pelaksanaan pengelolaan Pasal 3

${ }^{12}$ Undang-Undang Nomor 23 Tahun 2011 tentang Pengelolaan Zakat

Peraturan Menteri Agama Republik Indonesia, Nomor 18 Tahun 2016 tentang Organisasi dan Tata Kerja Sekretariat Badan Amil Zakat Nasional, Sekretariat BAZNAS Pasal 2 menyelenggarakan fungsi: ${ }^{13}$

a. koordinasi penyusunan rencana, program, kegiatan dan anggaran;

b. pengelolaan informasi dan pengembangan sistem informasi;

c. penyusunan peraturan dan advokasi hukum;

d. pelaksanaan urusan keuangan;

e. pelaksanaan organisasi dan tata laksana, kerja sama dan hubungan masyarakat;

f. pengelolaan administrasi kepegawaian;

g. pelaksanaan urusan tata usaha, rumah tangga, perlengkapan dan barang milik/kekayaan negara pada BAZNAS; dan

h. evaluasi dan pelaporan. zakat.

\section{6). Peraturan Menteri Keuangan} Nomor 162/PMK. 05/2013

Berdasarkan Peraturan Menteri Keuangan Nomor 162/Pmk. 05/2013 Tentang Kedudukan dan

13 Peraturan Menteri Agama Republik Indonesia, Nomor 18 Tahun 2016 tentang Organisasi dan Tata Kerja Sekretariat Badan Amil Zakat Nasional, Sekretariat BAZNAS 
Fitria Kusumawardhani

Tanggung Jawab Bendahara pada Satuan Kerja Pengelola Anggaran Pendapatan dan Belanja Negara Laporan Pertanggungjawaban Bendahara yang selanjutnya disingkat LPJ adalah laporan yang dibuat oleh Bendahara atas uang yang dikelolanya sebagai pertanggungjawaban pengelolaan uang Bendahara. Pasal 1 angka 15 Pengeluaran Pembantu yang selanjutnya disingkat BPP adalah orang yang ditunjuk untuk membantu Bendahara Pengeluaran untuk melaksanakan pembayaran kepada yang berhak guna kelancaran pelaksanaan kegiatan tertentu. ${ }^{14}$

\section{7). Peraturan Presiden Republik}

Indonesia Nomor 192 Tahun 2014

Tentang Badan Pengawasan

Keuangan dan Pembangunan (BPKP)

Badan Pengawasan Keuangan

dan Pembangunan

(BPKP)

Berdasarkan Peraturan Presiden RI Nomor 192 Tahun 2014 Pada point

14 Peraturan Menteri Keuangan Nomor 162/Pmk. 05/2013 Tentang Kedudukan dan Tanggung Jawab Bendahara pada Satuan Kerja Pengelola Anggaran Pendapatan dan Belanja Negara mengingat Peraturan Presiden Republik Indonesia Nomor 192 Tahun 2014 terdapat UndangUndang Nomor 30 Tahun 2002 tentang Komisi Pemberantasan Tindak Pidana Korupsi, maka Pendekatan yang dilakukan BPKP diarahkan lebih bersifat preventif atau pembinaan dan tidak sepenuhnya audit atau represif. Kegiatan sosialisasi, asistensi atau pendampingan dan evaluasi merupakan kegiatan yang mulai digeluti BPKP, sedangkan audit investigatif dilakukan dilakukan dalam membantu aparat penegak hukum untuk menghitung kerugian keuangan negara.

Pasal 3 ayat (1) Perumusan kebijakan nasional pengawasan intern terhadap akuntabilitas keuangan negara/daerah dan pembangunan nasional meliputi kegiatan yang bersifat lintas sektoral, kegiatan kebendaharaan umum negara berdasarkan penetapan oleh Menteri Keuangan selaku Bendahara Umum Negara, dan kegiatan lain berdasarkan penugasan dari Presiden. Bendahara Umum Pemerintah atas Badan Pengawasan Keuangan dan 
Pembangunan (BPKP) Pendekatan yang dilakukan BPKP diarahkan lebih bersifat preventif atau pembinaan dan tidak sepenuhnya audit atau represif. Kegiatan sosialisasi, asistensi atau pendampingan dan evaluasi merupakan kegiatan yang mulai digeluti BPKP, sedangkan audit investigatif dilakukan dilakukan dalam membantu aparat penegak hukum untuk menghitung kerugian keuangan negara. Perumusan kebijakan nasional pengawasan intern terhadap akuntabilitas keuangan negara/daerah dan pembangunan nasional meliputi kegiatan yang bersifat lintas sektoral, kegiatan kebendaharaan umum negara berdasarkan penetapan oleh Menteri Keuangan selaku Bendahara Umum Negara, dan kegiatan lain berdasarkan penugasan dari Presiden. ${ }^{15}$

\section{IIII. PENUTUP}

\section{A. Kesimpulan}

15 Peraturan Presiden Republik Indonesia, Nomor 192 Tahun 2014 tentang Badan Pengawasan Keuangan dan Pembangunan
1. Pemberian Sanksi Dana Zakat Badan Amil Zakat (BAZ) kepada Bendahara Pemerintah di Kota Pagalaram

Titik sentral teori lembaga legislatif Islam adalah syura. Kata ini disebutkan satu kali dalam al-qur'an. Para pemikir politik Islam menjadikan kata syura ini sebagai landasan normatif teori lembaga legislatif Islam. Ada beberapa definisi syura yang diberikan beberapa pemikir muslim. Pertama syura adalah meminta pendapatan kepada para ahli untuk mengambil kebijakan yang dekat kepada kebenaran. Kedua syura adalah meminta pendapat kepada umat atau yang mewakilinya dalam masalahmasalah yang berhubungan dengan kepentingan publik. Ketiga, syura adalah wahana peran serta masyarakat dalam rangka tukar pendapat dalam membuat kebijakan publik. Kepentingan keuangan atau kepentingan lain dari Pemerintah Pusat dan atau Pemerintah Daerah serta akuntabilitas pembiayaan keuangan negara atau daerah; sehingga berdasarkan penghitungan 
oleh BPKP, menemukan di Badan Amil Zakat temuan Tindak Pidana ini diduga dilakukan tersangka sejak 2004 tahun 2014, sehingga dalam kurun waktu 13 tahun berdasarkan hasil audit

Kerugian keuangan negara mencapai Rp 659.025.311 dan dikenakan ancaman Pasal 2 ayat (1) dan ayat (2) Undang-Undang Nomor 31 Tahun 1999 dan Pasal 8 UndangUndang Nomor 20 Tahun 2001 tentang Tindak Pidana Korupsi mencapai Rp 659.025.311 dan dikenakan ancaman Pasal 2 ayat (1) dan ayat (2) Undang-Undang Nomor 31 Tahun 1999 dan Pasal 8 UndangUndang Nomor 20 Tahun 2001 tentang Tindak Pidana Korupsi. Namun di Kota Pagaralam serta merta penggelapan dana dilakukan secara berkelompok oleh Surimawati Bendahara Gaji Sauan Polisi Pamong Kota Pagaralam, Listianawati Bendahara Gaji Kecamatan Pagaralam Utara, Legimin Gaji Bendahara Gaji Pekerjaan Umum dan Mukamin Bendahara Gaji Dinas Peternakan dan Perikanan Kota Pagaralam, sehingga tepat apabila negara menerapkan Pasal 8 Dipidana dengan pidana penjara paling singkat 3 (tiga) tahun dan paling lama 15 (lima belas) tahun dan pidana denda sedikit Rp150.000.000,00 (seratus lima puluh juta rupiah) dan paling banyak Rp750.000.000,00 (tujuh ratus lima puluh juta rupiah).

Pegawai negeri atau orang selain pegawai negeri yang ditugaskan menjalankan suatu jabatan umum secara terus menerus atauuntuk sementara waktu, dengan sengaja menggelapkan uang atau surat berharga yang disimpan karena jabatannya, atau membiarkan uang atau surat berharga tersebut diambil atau digelapkan oleh orang lain, atau membantu dalam melakukan perbuatan tersebut. Sehingga tepat apabila negara menerapkan Pasal 8 dari Undang-Undang Nomor 20 Tahun 2001 tentang Pemberantasan Tindak Pidana Korupsi dipidana dengan pidana penjara paling singkat 3 (tiga) tahun dan paling lama 15 (lima belas) tahun dan pidana denda sedikit Rp150.000.000,00 (seratus lima puluh juta rupiah) dan paling banyak Rp750.000.000,00 (tujuh 
ratus lima puluh juta rupiah), pegawai negeri atau orang selain pegawai negeri yang ditugaskan menjalankan suatu jabatan umum secara terus menerus atauuntuk sementara waktu, dengan sengaja menggelapkan uang atau surat berharga yang disimpan karena jabatannya, atau membiarkan uang atau surat berharga tersebut diambil atau digelapkan oleh orang lain, atau membantu dalam melakukan perbuatan tersebut.

Lebih menjamin kepastian hukum, menghindari keragaman penafsiran hukum dan memberikan perlindungan terhadap hak-hak sosial dan ekonomi masyarakat, serta perlakuan secara adil dalam memberantas tindak pidana korupsi, maka ke empat Bendahara Gaji di Pemerintah Kota Pagaralam divonis satu atau tiga penjara.

\section{Perjanjian antara Badan Amil Zakat kepada Bendahara Pemerintah}

Kasus penggelapan dana dari Dana Amilin Zakat (BAZ) di kota Pagalaram, analisa penulis. Pada tahap pelaksanaan perjanjian, para pihak harus melaksanakan apa yang telah dijanjikan atau apa yang yang telah menjadi kewajibannya dalam perjanjian tersebut. Kewajiban memenuhi apa yang dijanjikan tersebut. Kewajiban prestasi, sedangkan apabila salah satu pihak atau bahkan kedua pihak tidak melaksanakan kewajibannya sesuai dengan perjanjian yang telah dibuatnya, itulah yang disebut dengan wanprestasi. Suatu perbuatan hukum yang bersegi satu adalah setiap perbuatan yang berakibat hukum (rechtsgelog) dan akibat hukum ditimbulkan oleh kehendak satu subyek hukum, yaitu satu pihak, saja (yang telah melakukan perbuatan itu).

Suatu perbuatan hukum yang bersegi dua adalah setiap perbuatan yang akibat hukumnya ditimbulkan oleh kehendak dua subyek hukum, yaitu itu suatu perbuatan yang menyebbakan satu orang (subyek hukum) atau lebih mengikat dirinya pada seseorang (subyek hukum) 1 : dua fihak atau lebih. Setiap perbuatan hukum yang bersegi dua merupakan perjanjian 
(oovereenkomst), pasal 1313

ain). Pembayaran dapat dilaksanakan

KUHPerdata "Perjanjian lain atau lebih.” Badan Usaha Milik Negara dan badan usaha milik daerah merupakan subjek pajak tanpa memperhatikan nama dan bentuknya sehingga setiap unit tertentu dari badan pemerintah, misalnya lembaga, badan dan sebagainya yang dimiliki oleh Pemerintah Pusat dan Pemerintah Daerah yang menjalankan usaha atau melakukan kegiatan untuk memperoleh penghasilan merupakan subyek pajak. Dalam pengertian perkumpulan termasuk pula asosiasi, persatuan, perhimpunan, atau ikatan dari pihak-pihak yang mempunyai kepentingan yang sama.

Meng-qiyas-kan zakat profesi dengan zakat emas atau perdagangan secara mutlak, mengignat karena kedua-duanya berbentuk usaha (kasab al-amal). Maka nishabnya senilai 85 gram emas murni, zakatnya $2,5 \%$ mempertimbangkan haul, dan seluruh pendapatan dalam tahun itu dijumlahkan dengan asumsi bahwa zakat adalah kewajiban yang dibebankan kepada nilainya (alqimah), bukan kepada materinya (alpada akhir tahun (haul) atau dicicil pada setiap menerima gaji atau hasil profesi. (Fiqh al-zakat, 1/59-520). Ketentuan dalam pengambilan zakat pegawai negeri ialah 2,5 persen dari jumlah penghasilan perbulan yang dilakukan terus-menerus oleh Anggota BAZNAS.

Peraturan Menteri Agama Republik Indonesia, Nomor 18 Tahun 2016 tentang Organisasi dan Tata Kerja Sekretariat Badan Amil Zakat Nasional, Sekretariat BAZNAS Pasal 2 menyelenggarakan fungsi:

a. koordinasi penyusunan rencana, program, kegiatandan anggaran;

b. pengelolaan informasi dan pengembangan sistem informasi;

c. penyusunan peraturan dan advokasi hukum;

d. pelaksanaan urusan keuangan;

e. pelaksanaan organisasi dan tata laksana, kerja sama dan hubungan masyarakat;

f. Pengelolaan administrasi kepegawaian;

g. pelaksanaan urusan tata usaha, rumah tangga, perlengkapan dan barang milik/kekayaan negara pada BAZNAS; dan

h. evaluasi dan pelaporan zakat.

Ditahap pelaksanaan kerja sama pihak Bendahara Pemerintah, 
ternyata Bendahara Pemerintah melakukan penggelapan dana yang seharusnya tidak terjadi. Pendekatan yang dilakukan BPKP diarahkan lebih bersifat preventif atau pembinaan dan tidak sepenuhnya audit atau represif. Kegiatan sosialisasi, asistensi atau pendampingan dan evaluasi merupakan kegiatan yang mulai digeluti BPKP, sedangkan audit investigatif dilakukan dilakukan dalam membantu aparat penegak hukum untuk menghitung kerugian keuangan negara. Pada Point mengingat Undang-Undang Nomor 30 Tahun 2002 tentang Komisi Pemberantasan Tindak Pidana Korupsi Pasal 1 Peraturan Presiden Republik Indonesia Nomor 192 Tahun 2014 Tentang Badan Pengawasan Keuangan dan Pembangunan (BPKP) ialah Perumusan kebijakan nasional pengawasan intern terhadap akuntabilitas keuangan negara/daerah dan pembangunan nasional meliputi kegiatan yang bersifat lintas sektoral, kegiatan kebendaharaan umum negara berdasarkan penetapan oleh Menteri Keuangan selaku Bendahara
Umum Negara, dan kegiatan lain berdasarkan penugasan dari Presiden.

B. Saran

Peran Badan Pengawasan Keuangan dan Pembangunan (BPKP) merumuskan kebijakan nasional pengawasan intern terhadap akuntabilitas keuangan negara/daerah dan pembangunan nasional meliputi kegiatan yang bersifat lintas sektoral, kegiatan kebendaharaan umum negara berdasarkan penetapan oleh Menteri Keuangan selaku Bendahara Umum Negara, dan kegiatan lain berdasarkan penugasan dari Presiden.Pendekatan yang dilakukan BPKP diarahkan lebih bersifat preventif atau pembinaan dan tidak sepenuhnya audit atau represif. Kegiatan sosialisasi, asistensi atau pendampingan dan evaluasi merupakan kegiatan yang mulai digeluti BPKP, sedangkan audit investigatif dilakukan dilakukan dalam membantu aparat penegak hukum untuk menghitung kerugian keuangan negara, jadi permasalahan diatas kegiatan kebendaharaan umum negara di awasi oleh berdasarkan penetapan oleh Menteri Keuangan 
selaku Bendahara Umum Negara, dan kegiatan lain berdasarkan penugasan dari Presiden melalui BAZNAS dan Badan Pengawasan Keuangan dan Pembangunan (BPKP).

Beberapa lembaga resmi yang dibentuk untuk pengelolaan zakat berdasarkan peraturan ialah :

1. Badan Amil Zakat (BAZNAS)

2. Lembaga Amil Zakat (LAZ)

3. Unit Pengumpul Zakat (UPZ)

Harmonisasi dan koordinasi antara sektoral dapat memajukan perekonomian negara yang bersumber dari pajak yang dipungut setiap bulan dari Bendahara Pemerintah di seluruh Instansi untuk menghindari penggelapan dana dan ata fiktif maka Badan Pengawasan Keuangan dan Pembangunan (BPKP) amat penting, kasus Bendahara Pemerintah dan Pegawai Badan Amil Zakat (BAZ) disebabkan zakat merupakan faktor penting bagi dunia islam terhadap subyek masingmasing pribadi yang dikelola oleh Badan Amil Zakat yang keuangannya harus diawasi oleh Badan Pengawasan Keuangan dan Pembangunan (BPKP).

\section{DAFTAR PUSTAKA}

\section{A. Buku}

Achmat

Subakan,2016,Jurnal

Potensi Zakat menjadi Bagian Keuangan Negara. Balai

Diklat Keuangan:Malang

Prof. Dr. Ahmadi Miru, S.H., M.S,2008,Hukum Perikatan : Penjelasan Makna Pasal 1233 sampai $1456 B W$, Rajawali Press: Jakarta

Drs. Dalizar Putra,1995, Hak Asasi Manusia Menurut Al-Qur'an. PT. Al-Husna Zikra : Jakarta

Gus Arifin, 2016, Keutamaan Zakat, Infak, Sedekah. PT Elex Media Komputindo, Kelompok Gramedia - Anggota IKAPI : Jakarta

Dr.H.Salim. S.H., M.H, 2013, Penerapan Teori Hukum pada Penelitian Tesis dan Disertasi, PT.Raja Grafindo Persada : Jakarta 
Warkum Sumitro, 2015, Legislasi :

Hukum Islam Transformaitif, Setara Press : Malang

Peraturan Perundang-Undangan

Al-qur'an, Tafsir Al-Usyr Al-Akhir, Cetakan IV

Undang-Undang Nomor 31 Tahun 1999 tentang Pemberantasan Tindak Pidana Korupsi

Undang-Undang Nomor 20 Tahun 2001 tentang Pemberantasan Tindak Pidana Korupsi

Undang-Undang Nomor 36 Tahun 2008 tentang Pajak Penghasilan

Undang-Undang Nomor 23 Tahun 2011 tentang Pengelolaan Zakat

Peraturan Menteri Keuangan Nomor 162/PMK. 05/2013 Tentang Kedudukan dan Tanggung Jawab Bendahara pada Satuan Kerja Pengelola Anggaran Pendapatan dan Belanja Negara

\begin{tabular}{|c|c|}
\hline \multirow{2}{*}{\multicolumn{2}{|c|}{ Presiden }} \\
\hline & \\
\hline 2014 & Tentang \\
\hline
\end{tabular}

Pengawasan Keuangan dan Pembangunan (BPKP)

Peraturan Menteri Agama Republik Indonesia, Nomor 18 Tahun 2016 tentang Organisasi dan Tata Kerja Sekretariat Badan Amil Zakat Nasional, Sekretariat BAZNAS

\section{B. Jurnal}

Jurnal Pendayagunaan Zakat di Badan Amil Zakat Nasional Kota Pekanbaru Berdasarkan Undang-Undang Nomor 23 Tahun 2011 tentang Pengelolaan Zakat, Muhammad Azani, Volume 17 Nomor 1 Tahun 2017

Jurnal Potensi Zakat Menjadi Bagian Keuangan Negara, Achmat Subekan, Volume 7 Nomor 2 Tahun 2016

\section{Website}

Wibowo Pajak, ,Artikel Pajak untuk Bendahara Pemerintah, http://www.wibowopajak.com/20 12/01/pajak-untuk-bendaharapemerintah.html, 2018 
Volume 17, No. 2, Oktober 2019

Sriwijaya Pos, Empat Bendahara

Gaji di Pemkot Pagalaram

Terbukti Korupsi Divonis Satu

hingga Tiga Tahun Penjara,

palembang.tribunews, 2017

diakses tanggal 11 September

2018 